\title{
Nuclear Expression of STAT6 Protein
}

National Cancer Institute

\section{Source}

National Cancer Institute. Nuclear Expression of STAT6 Protein. NCI Thesaurus. Code C129525.

A finding indicating the presence of STAT 6 nuclear signal in tumor cells by immunohistochemistry. It results from the fusion of the NAB2 and STAT 6 genes. 